\title{
Trzy Deklaracje praw człowieka i obywatela - zmienne pryncypia Wielkiej Rewolucji Francuskiej
}

\begin{abstract}
One of the symbols of the Great French Revolution was the Declarations of the Rights of Man and of the Citizen - a document adopted by the National Constituent Assembly on August 26, 1789, collecting fundamental rights and the constitutional principles of a democratic state. It later became a lofty introduction to the 1791 constitution. The French had yet to receive two declarations, attached to the following basic acts - from 1793 and 1795. Their content was different, and even when some of their rights were repeated, they often differed in their approach, which indicated the changing ruling teams, their political programs, and their social background. In addition to indicating the differences between the three declarations, the article shows in particular the inspirations of the first (most important) of them - basically the influence of the Enlightenment thought and the declaration of the laws of the states of North America. The author draws attention to the differences between the American and French approaches to human rights. Despite the fact that after 1795 no further declaration of rights was ever made in France, the achievements of the Great French Revolution, and especially the 1789 document, remain today a point of reference for democrats in France and all over the world.
\end{abstract}

1 Zbigniew Filipiak, Katedra Powszechnej Historii Państwa i Prawa, Wydział Prawa i Administracji, Uniwersytet Mikołaja Kopernika w Toruniu, Polska, filipiak@umk.pl. 


\section{Keywords:}

France, revolution, Declarations of Rights, human rights, Constitution, democracy

Celem niniejszego artykułu jest wykazanie najistotniejszych różnic w trzech Deklaracjach praw człowieka i obywatela w kontekście zmieniających się uwarunkowań politycznych i społecznych rewolucyjnej Francji. Deklaracje bowiem, odbierane już przez współczesnych jako fundamenty ideowe i prawne nowego porządku, niczym imponujące lustra Galerii Zwierciadlanej Pałacu Wersalskiego, wiernie odbijały przekonania i ambicje kolejnych ekip rządowych, które nie ustawały w zabiegach, aby przedstawiać to jako wolę ludu. Należy w szczególności zwrócić uwagę na korzenie pierwszego z trzech dokumentów, niewątpliwie najważniejszego i mającego wpływ odczuwalny do dnia dzisiejszego. Francuskie osiągnięcia w dziedzinie unormowań zasadniczych praw podmiotowych i publicznych były wykorzystywane przez szereg demokracji europejskich i światowych oraz pomogły w stworzeniu międzynarodowych regulacji praw człowieka, z Powszechną deklaracją praw człowieka na czele.

\section{DEKLARACJA PIERWSZA (1789)}

Za główne źródła inspiracji Deklaracji z 1789 roku (Duguit, Monnier, 1952, s. 1-3) uznaje się pisma oświeceniowych filozofów oraz Deklarację niepodległości jednoczących się w 1776 roku stanów Ameryki Północnej, a także deklaracje poszczególnych stanów, takich jak Wirginia, Maryland czy Massachussets. Idąc dalej tym śladem, wskazywano również na pośrednie wzorce angielskie - Bill of Rights, Habeas Corpus Act, Petition of Rights, a nawet Magna Charta Libertatum. Sam twórca projektu - czyli „bohater dwóch światów” - generał Marie La Fayette przyznał w swoich pamiętnikach, że bezpośrednim natchnieniem stały się dla niego deklaracje praw dołączane do konstytucji stanowych. Trudno zresztą o inny scenariusz, skoro Deklaracja niepodległości to dokument skupiający się na wyliczeniu niesprawiedliwości, jakich doświadczali koloniści od brytyjskiego rządu, z których dopiero wnikliwy interpretator może zrekonstruować zestaw praw człowieka i obywatela przyświecający Amerykanom. Elementy wyraźnie łączące dzieło komisji pod wodzą Thomasa Jeffersona z aktem z 26 sierpnia 1789 roku to wyrażona zasada wolności i równości (wszyscy rodzą się według Deklaracji 
niepodległości równi, obdarzeni przez Stwórcę niezbywalnymi prawami, takimi jak prawo do życia, wolności i dążenia do szczęścia²), zasada suwerenności ludu (tekst z 1776 roku mówi o rządach, których sprawiedliwa władza wywodzi się ze zgody rządzonych, zaś dokument z 1789 roku, że źródło wszelkiej władzy tkwi w narodzie (art. 3). Oba pomniki prawa deklarują również prawo oporu, zmiany niesprawiedliwego rządu. Przy tym należy zaznaczyć, że sformułowanie owych zasad różni oba dokumenty. W szczególności tekst amerykański jasno odwołuje się do chrześcijańskiego Boga, francuski zaś - do deistycznej Istoty Najwyższej (w preambule³). Będzie o tym jeszcze mowa w dalszej części artykułu. Z kolei deklaracje stanowe były w ówczesnej Francji znane, gdyż francuskie tłumaczenia były publikowane w latach 1778 i 1783 (Jellinek, 1905, s. 24-26). Spośród deklaracji stanowych niewątpliwie największe znaczenie miał dokument z Wirginii - uchwalony jako pierwszy po wezwaniu Kongresu Kontynentalnego z 15 maja 1776 roku. Głównym autorem projektu był Georg Mason - współtwórca również samej ustawy zasadniczej Wirginii. Co ciekawe, ten zasłużony dla unii polityk sprzeciwił się później przyjętemu przez Kongres tekstowi konstytucji federalnej. Jednym z tego powodów było pominięcie w oryginalnym tekście deklaracji praw obywatelskich. Mason zmarł w 1792 roku, zatem dożył ratyfikacji przez stany pierwszych poprawek do konstytucji, które zawierały prawa obywatelskie, notabene również bazujące na wzorach z Wirginii.

W swej ważnej pracy z 1905 roku poświęconej Deklaracji, Georg Jellinek porównywał fragmenty tekstów amerykańskich i francuskiego, dowodząc braku oryginalności dzieła La Fayette’a:

Francuzi nie zdobyli się na żaden oryginalny pomysł prawny, do wyszczególnień amerykańskich nie dodali żadnego odrębnego prawa wolności. Przeciwnie, brak w deklaracji francuskiej tak ważnego prawa o związkach i zebraniach, prawa wolności przesiedlania się, prawa petycji, które pojawiają się dopiero 3 września 1791 roku wśród naturalnych i obywatelskich praw przez konstytucję gwarantowanych (Jellinek, 1905, s. 46).

Zwracał przy tym uwagę, że jeśli już dowodzić w tekście Deklaracji z 1789 roku rodzimego rodowodu przepisów, to miało to znaczenie bardziej polityczne,

2 Art. 1 Deklaracji z 26 VIII 1789 roku - „Wszyscy rodzą się i pozostają wolni oraz równi wobec praw. Różnice społeczne mogą być powodowane jedynie pożytkiem ogółu”.

3 Zakończenie preambuły: „W związku z tym Zgromadzenie Narodowe uznaje i ogłasza, w obecności i pod auspicjami Istoty Najwyższej, następujące prawa człowieka i obywatela”. 
niźli stricte prawne. Definicje wolności (art. 4) oraz ustaw tworzonych w realiach demokratycznych (art. 5 i 6) uznał wręcz za zbyteczne. Podkreśloną po wielokroć zasadę równości wobec prawa (zwłaszcza w art. 4, 6 i 13) tłumaczył tym, że była ona dla Francuzów nowością, kiedy stosunki społeczne w Ameryce były jej bliższe od dawna. W tej mierze miał też odznaczyć się wpływ popularnej nad Sekwaną Umowy społecznej Jana Jakuba Rousseau. Z kolei ostrożniejsze sformułowanie gwarancji swobody wyznania tłumaczył przywiązaniem do katolicyzmu mas ludowych, a także członkostwem osób duchownych w Konstytuancie (Jellinek, 1905, s. 44-46).

Swego czasu poglądy Jellinka wywołały burzę nad Sekwaną. Francuzi poczuli się ze wszech miar urażeni tym, że odbiera się im palmę pierwszeństwa w zasługach dla spisania prawno-człowieczego kodeksu4 ${ }^{4}$ Trudno o bardziej absurdalne pole do narodowych ambicji i waśni niż przestrzeń praw podmiotowych i zasad demokratycznego państwa, która rychło zyskała wymiar uniwersalny. Powszechna i naturalna akceptacja tych osiągnięć dowodzi przecież różnorakich ich źródeł i wzajemnych inspiracji. Bez deklaracji amerykańskich, francuska wyglądałaby inaczej i nie wywarłaby tak głębokiego wpływu na kontynentalną kulturę prawa. Z drugiej strony dorobek francuskiej myśli oświeceniowej był współodpowiedzialny za bunt kolonistów wobec brytyjskiego hegemona, jego ideologiczne zaplecze. „Dla dzisiejszego badacza ważniejsza jest konstatacja, że zarówno deklaracje amerykańskie, jak i francuskie wyrastały ze wspólnego pnia ideologii prawa natury postaci, jaką nadało jej europejskie Oświecenie; że reprezentowały ten sam model regulacji praw człowieka, zwany - w odróżnieniu od modelu angielskiego - kontynentalnym” - pisze Katarzyna Sójka-Zielińska, wskazując przy okazji, że podatny grunt dla doktryny prawnonaturalnej w Ameryce dała nie tylko polityka, ale m.in. sama postać odkrywanego i zawłaszczanego lądu, tak bliskiego wizjom „stanu natury”, jaki kreślili pisarze z Rousseau na czele (Sójka-Zielińska, 2010, s. 139-140). Jakże smutne konstatacje wywołuje jednak ta myśl, kiedy zdamy sobie sprawę, jak szybko i bezwzględnie biali osadnicy ów „stan natury” pogrzebali wraz z rzeszami Indian.

Jakkolwiek nietrudno przychodzi dowodzić braku oryginalności i innych felerów dzieła roku 1789, to przecież nie sposób do dziś nie być poruszonym, czytając Deklarację (o ile jest się przekonań demokratycznych, rzecz jasna). Tekst

4 Jellinek, profesor prawa konstytucyjnego z Heidelbergu, wystąpił ze swoimi tezami po raz pierwszy w 1895 roku. Głosem oburzenia odpowiedział mu francuski politolog i socjolog z prawniczym wykształceniem Émile Boutmy. Wywołało to szerzej zakrojony i trwający kilka dekad spór pomiędzy uczonymi francuskimi i niemieckimi, skutecznie podsycany akcentami nacjonalistycznymi (Sójka-Zielińska, 2010, s. 139). 
francuski niejednokrotnie potrafi przewyższyć amerykańskie modele. Przykładem jeden z najdobitniejszych i najpiękniejszych fragmentów, art. 16 - „Społeczeństwo, w którym rękojmie praw człowieka nie są zabezpieczone, ani podział władzy nie jest ustalony, nie ma konstytucji”. Trudno go porównać z o wiele mniej wyrazistymi odpowiednikami z amerykańskich deklaracji stanowych. New Hampshire: „Ludzie, łącząc się w społeczeństwo, zrzekają się niektórych swych przyrodzonych praw na rzecz ogółu, w celu zabezpieczenia sobie jego opieki; bez takiego odpowiednika zrzeczenie się nie miałoby wartości”. Massachusetts: „W rządzie tego społeczeństwa wydział prawodawczy nie może nigdy sprawować władzy wykonawczej i sądowej, lub którejkolwiek z nich; wydział sądowniczy nie może nigdy sprawować władzy prawodawczej i wykonawczej, lub którejkolwiek z nich; wydział wykonawczy nie może nigdy sprawować władzy prawodawczej i sądowej, lub którejkolwiek z nich, a to w celu, by rządziły prawa, nie zaś ludzie” (Jellinek, 1905, s. 42-43).

Idea spisania praw człowieka i obywatela pojawiła się we Francji jeszcze przed zwołaniem Stanów Generalnych - postulat ten, a nawet stosowne szkice projektów zawarto w szeregu Cahiers de doléances - czyli w Zeszytach zażaleń, jakie przedstawiciele stanów spisywali od marca 1789 roku (Jellinek, 1905, s. 22). Podkreśla się jednak, że wyraz Zeszytów był zachowawczy, i to również w przypadku pism stanu trzeciego. Dopiero zebranie Zgromadzenia nakręciło spiralę ambicji posłów. Za jeden z najważniejszych etapów owej progresji nastrojów uznaje się zresztą okres 20-26 sierpnia, czyli czas uchwalania Deklaracji przez Konstytuantę. Projekt został złożony przez La Fayette’a 11 lipca, za namową Thomasa Jeffersona (wówczas ambasadora USA) i musiał stawić czoła szerokiej konkurencji, wśród której błyszczały propozycje tak poważanych autorytetów jak ksiądz Emanuel Sieyès czy Jean Joseph Mounier. O tym, że to właśnie projekt La Fayette'a będzie podlegał dalszym pracom, zdecydowano 19 sierpnia. Postrzegano go jako umiarkowany, mniej efektowny, lecz pozbawiony kardynalnych błędów (Morabito, Bourmaud, 1996, s. 67, 76-77).

Poza pierwszymi słynnymi artykułami, układ kilkunastu następnych, z jakich składa się Deklaracja nie sprawia wrażenia systematycznego, szczególnie przemyślanego. Po ostatnim, siedemnastym artykule, niezwykle istotnym, bo gwarantującym ochronę własności prywatnej (i to również przed pochopnymi ingerencjami państwa), dokument nagle się urywa, a czytelnik pozostaje w niedosycie. W rzeczywistości członkowie Konstytuanty planowali wrócić do uchwalonej materii praw podstawowych, przejrzeć ją, zrewidować i rozszerzyć, jednak miało stać się to dopiero po spisaniu konstytucji, nad czym prace zainicjowano już 27 sierpnia. W ostateczności do czasu uchwalenia ustawy zasadniczej tekst 
Deklaracji zyskał status uświęcenia, zatem już go potem nie modyfikowano, zaś dodatkowe prawa, co do których uznano, że zabrakło ich w tekście z 26 sierpnia 1789 roku, dopisano po prostu do samej konstytucji - tekstu uchwalonego 3 września 1791 roku. Deklaracja stała się jej tryumfalnym wstępem. Tu warto dodać, że część projektów Deklaracji pisano już jako początkowe części konstytucji (Morabito, Bourmaud, 1996, s. 76-77).

Wolność, własność, bezpieczeństwo i opór przeciw uciskowi - hierarchia naturalnych i nieprzedawnialnych praw człowieka i obywatela w dokumencie z 1789 roku (art. 2) przywołuje najsłynniejszych piewców prawa natury, Johna Locke’a oraz Monteskiusza. Najważniejsza jest wolność, wytłumaczona w art. 4 w sposób negatywny, ograniczona jedynie uprawnieniami innych ludzi oraz ustawami ${ }^{5}$. Tak klaruje się liberalna wizja państwa i prawa. Podkreśla się, że kluczowe znaczenie dla ideologicznej bazy Deklaracji z 1789 roku miał dorobek rodzimego fizjokratyzmu, którego przedstawiciele tacy jak François Quesnay czy Pierre-Paul Lemercier de La Rivière również zwracali się ku niezmiennym, obiektywnym prawom, którym winno podporządkować zarówno działalność gospodarczą, jak i sposób rządzenia państwem. Stąd, mimo dostosowania tych koncepcji do politycznych uwarunkowań absolutyzmu, fizjokraci twierdzili, że władca (absolutny, ale i zarazem oświecony) nie stoi ponad prawami natury, może być oceniany w ich aspekcie, ma dbać o poddanych, uznając ich niezbywalne prawa (do majątku i wolności osobistej). Obiektywność tychże zasadniczych uprawnień człowieczych powodowała, że ustawodawca nie mógł być postrzegany jako ich kreator, a jedynie jako odkrywca, który ogłaszał je, deklarował. Tak oto narodziła się koncepcja spisywania deklaracji praw (Sójka-Zielińska, 2010, s. 147).

Zasady zawarte w dokumencie z 1789 roku z jednej strony wytyczają granice władzy państwowej, z drugiej - określając prawa obywatela, widzą je w kontekście ściśle legalistycznym - ma on zachowywać się w granicach zakreślonych przez prawo. Podobnie widział to Jan Jakub Rousseau w Umowie społecznej - w miejsce

5 W pracach nad Deklaracją i następnie konstytucją rozważano dwa modele wolności - antyczną i anglosaską. Pierwsza skupiała się na szeroko rozumianej partycypacji obywateli w życiu publicznym, stąd bliska była poglądom J.J. Rousseau, popularnym wśród Francuzów. Drugi model to wolność w pojęciu liberalnym, z autonomią jednostki, którą ograniczają normy prawa, jednak jedynie w stopniu minimalnym, dając pełne szanse na rozwój i poszerzanie swobód człowieka. Ta koncepcja była z kolei najbliższa pismom J. Locke’a. Egalitarystom udało się unieszkodliwić próby dodania do Deklaracji zapisów sankcjonujących cenzus majątkowy jako podstawę do uczestniczenia w życiu politycznym i piastowania godności publicznych. Z kolei liberalna postać zasady wolności z art. 4 zezwalająca na wszystko, co nie szkodzi innym i nie jest zakazane ustawami, wywołała sprzeciwy zwłaszcza posłów duchownych, którzy widzieli w niej odejście od moralności nauczanej przez Kościół (Baszkiewicz, 2002, s. 65-68). 
naturalnych praw człowieczych wchodzą prawa obywatela ${ }^{6}$. Władza, gwarantując szereg uprawnień, nie ma zamiaru odmówić sobie narzędzi do ich limitowania. Na bardziej zdecydowane oparcie się na egalitarnych koncepcjach filozofa z Genewy trzeba było jeszcze trochę poczekać. Równość to w Deklaracji z 1789 roku przekreślenie dawnego systemu stanowości, to równość wobec prawa (art. 6), czyli ustaw, sądów. Daleka od równości w rozumieniu arytmetycznym, dotyczyć ma ludzi będących w tej samej sytuacji, gdzie nie występują pewne obiektywne różnice, takie jak wiek, płeć, a nade wszystko status majątkowy (Sójka-Zielińska, 2010, s. 149-150).

W wydanej w 1907 roku broszurze Deklaracja praw człowieka i obywatela Stanisław Posner zwracał uwagę na różnicę pomiędzy deklaracjami amerykańskimi i deklaracją francuską: „Deklaracja amerykańska była dziełem praktyków życiowych, urodziła się z bezpośredniej potrzeby życia. Deklaracja francuska była objawieniem filozofów raczej i bohaterów, którzy, dla Francuzów pracując, mieli na myśli ludzkość całą i pracując, walcząc i ginąc, w obronie pewnego momentu historycznego, mniemali, że żyją dla wieczności, i dla niej pracują”. Dalej Posner pisał o sztuczności aktu doczepienia Deklaracji do konstytucji z 1791 roku, wskazując na sprzeczności, takie jak cenzusowy system wyborczy wobec deklarowanej wcześniej równości wobec prawa. Dokument z 1789 roku wyznaczać miał zatem bardziej drogę rozwoju społeczeństwa, państwa, prawa, oświecaną filozoficznymi hasłami, do których realizacji miało dojść w przyszłości. I to nie tylko w granicach Francji - „dla ludzkości i dla wieczności” (Posner, 1907, s. 28). Jednocześnie był oczywiście ugruntowaniem kompromisu politycznego pomiędzy obozem królewskim, szlachtą i burżuazją. Oznaczał czas „pół-wolności” (demi-liberté), jak zwykł mówić o tamtym okresie Maksymilian Robespierre.

Z kolei Hannah Arendt już w tekście pierwszej Deklaracji znajduje dowód na „najdonośniejszą różnicę pomiędzy Rewolucją Amerykańską a Rewolucją Francuską”. Chodzi o wspomniany już tu artykuł 6 stanowiący, że prawo jest wyrazem Woli Powszechnej. Podobnego zapisu nie znajdzie się ani w Deklaracji niepodległości, ani w konstytucji USA. Arendt wywodzi stąd ciekawe wnioski o amerykańskim rozróżnianiu źródeł władzy tkwiących w narodzie od źródeł prawa usytuowanych „ponad, w jakimś wyższym, transcendentnym regionie”. Cytuje tutaj Johna Adamsa i jego określenie „wielkiego Prawodawcy Wszechświata” oraz

6 Skądinąd Baszkiewicz zauważa, że Deklaracja nie odbiera prawom obywatelskim miana praw natury, nieprzedawnialnych. Człowiek „nie roztapia się w upolitycznionym Obywatelu, jest nadal podmiotem praw natury, które w odróżnieniu od ustaw mają być wieczne (Baszkiewicz, 2002, s. 71; Morabito, Bourmaud, 1996, s. 79). 
wskazuje na wzmianki o „nagrodzie i karze w życiu przyszłym”, które co prawda nie trafiły do pomników prawa federalnego, ale można znaleźć je w konstytucjach stanowych. Francuskie zaś wyprowadzanie źródeł władzy i prawa z jednego źródła jest dla niej kontynuacją przyzwyczajeń z czasów absolutyzmu, kiedy mowa była o prawie boskim, znajdującym odbicie w obliczu monarchy, którego wola była prawem na wzór woli Stwórcy. Podobnie ma być z „Wolą Powszechną”, w której to konstrukcji Arendt widzi dowód na deifikację ludu - wola ta pozostaje w istocie „boska”, dla której powodem na tworzenie prawa wystarczająca jest sama chęć. Tak nagle potężny „lud” jest zdolny do największego dobra, ale i do największego zła7 . Wodzowie francuskiej rewolucji musieli zdawać sobie sprawę z tego niebezpieczeństwa, usiłując w miejsce skonfliktowanego z nimi Kościoła wstawić kult Istoty Najwyższej - osiągając mizerne czy wręcz karykaturalne skutki. Tempo rewolucyjne zaś przyśpieszało, radykalizując się. Już nie lud z jego wolą, lecz sam rewolucyjny proces stał się „źródłem wszystkich praw”, skutkiem czego najświeższe regulacje potrafiły być „przedawnione już w chwili wydania, bo obalało je Wyższe Prawo tej samej Rewolucji, która dopiero co je urodziła”. Perspektywa dopełnienia rewolucyjnego dzieła, uznania jego ostatecznego sukcesu i oddania się błogości powszechnego pokoju i szczęścia, okazywała się w tym ujęciu mało realna. Jedyną szansą na zatrzymanie tak rozjuszonej Rewolucji mogło być tylko polityczne przecięcie, kontrrewolucja (Arendt, 1991, s. 185-196). I tak też się w ostateczności stało.

O trudnych relacjach rewolucjonistów francuskich z Kościołem i samych związkach pomiędzy nurtami rewolucyjnymi a religijnymi napisano rzecz jasna wiele $^{8}$, lecz trudno nie wspomnieć tu słów Alexisa de Tocqueville’a:

7 O zastąpieniu suwerennego króla przez suwerenny lud oraz o pojmowaniu demokracji jako szczególnej formy religii por. Grzybowski, 1947, s. 55 i nast.

8 Edmund Burke pisał już w 1796 roku, że zniszczenie religii było wręcz podstawowym celem francuskich rewolucjonistów (ci w większości, z Robespierre’em na czele, byli w rzeczywistości bliżsi deizmowi niż ateizmowi). Za winnych Rewolucji uznawał dwie kategorie Francuzów - „polityków” i „filozofów”. Ci drudzy w szczególności upodobać sobie mieli walkę z religią: „Celowi temu podlegała każda kwestia dotycząca władzy. Woleli oni sprawować władzę nad gminą ateistów niż panować nad światem chrześcijańskim. Ich przejściowa ambicja była całkowicie uległa ich prozelitycznemu duchowi, któremu nie dorównywał sam Mahomet. [...] Ci którzy nie kochają religii, nienawidzą jej”. Politycy mieli być z kolei wobec religii obojętni, korzystali jednak z fanatyzmu filozofów: „Filozofowie aktywnie pełnili rolę wewnętrznych agitatorów, umacniając ducha i zasady. Politycy dawali praktyczne wskazówki. Czasem w układzie tym przeważali jedni, czasem drudzy. Jedyne co ich różniło, to potrzeba zatajenia na pewien czas ogólnego planu oraz sposób postępowania wobec obcych państw. Fanatycy działali bardziej bezpośrednio i otwarcie, działania polityków przyjmowały ostrożniejszy kształt zygzaka. Z biegiem wydarzeń stało się to jedną z przyczyn zaciekłych i krwawych sporów między nimi, ale zasadniczo byli zgodni we wszystkich sprawach 
Rewolucja Francuska jest więc rewolucją polityczną, która działa sposobami rewolucji religijnej i poniekąd przybrała jej wygląd. Zobaczmy, przez jakie to szczególne i znamienne cechy staje się całkiem podobna do rewolucji religijnych; nie tylko rozprzestrzenia się szeroko jak i one, ale, jak i one, szerzy się przez kaznodziejstwo i propagandę. Rewolucja polityczna zdobywająca sobie wyznawców, równie żarliwie głoszona wśród obcych, jak namiętnie przeprowadzana u siebie; zważcie, jak nowe jest to widowisko! [...] Rewolucja Francuska postępowała w stosunku do tego świata dokładnie tak samo, jak na rzecz życia na tamtym świecie działają rewolucje religijne; obywatelem zajmowała się abstrakcyjnie, poza jakimkolwiek określonym społeczeństwem, podobnie jak religie zajmują się człowiekiem w ogóle, niezależnie od jego kraju i czasu. Starała się określić nie tylko szczególne prawa obywatela francuskiego, ale i obowiązki i prawa powszechne ludzi w dziedzinie politycznej (de Tocqueville, 2005, s. 46-47).

Najbardziej atrakcyjnym wzorem dla świata okazała się właśnie Deklaracja praw człowieka i obywatela. Będzie ona niestety również niejednokrotnie nadużywana jako rzekome źródło inspiracji przez środowiska jak najbardziej dalekie od demokratycznych i wymuszające na swych zwolennikach quasi-religijną podwładność. Praktyczny wymiar stosowania tekstu z 1789 roku pozostawiał wszelako wiele do życzenia już od samego początku.

Uściślijmy, uszczerbkowi nie ulegała litera Deklaracji, gdyż ta z góry przewidywała ustawowe limitacje praw obywatelskich. Można jednak mówić o uszczerbku dla jej ducha i szczytności powziętych celów, kiedy przy zawężeniach swobód w grę wchodzić zaczęły typowo polityczne kalkulacje. Równość wobec prawa i wola powszechna jako źródło prawodawstwa znalazły skuteczne ograniczenie w konstrukcji obywatelstwa czynnego i biernego. Opracował ją ksiądz Emmanuel Sieyès, którego rozprawa Czym jest stan trzeci? otworzyła wiele umysłów w przededniu Rewolucji. Przeciwny wizjom demokracji bezpośredniej, o której marzył Rousseau, nie tylko popierał system przedstawicielski, ale przy użyciu cenzusu majątkowego wykluczył większość Francuzów z realnego życia politycznego ${ }^{9}$. Innym przykładem okazała się kwestia nienaruszalności własności

ambicji i bezbożności oraz zasadniczo co do wszystkich środków propagowania tych celów”. Dla zażartego wroga Rewolucji, jakim był konserwatysta Burke, zapewne jednym z naczelnych sposobów na ową propagandę były wynikające bezpośrednio z pism filozoficznych teksty Deklaracji (Burke, 2012, s. 289-291).

9 Wedle przyjętego jesienią 1789 roku cenzusu majątkowego obywateli podzielono na cztery kategorie - ostatnia z nich nie miała praktycznie żadnych praw politycznych. Kategoria trzecia 
prywatnej. Nie wstrzymało to procesu odbierania dóbr ziemskich Kościołowi i emigrantom podejrzewanym o poglądy sprzeczne z rządowymi. Wobec Kościoła używano argumentów, że jest to osoba prawna, korporacyjna, a Deklaracja stanowiła wszak o jednostkach. Osoba prawna to wszak dzieło ustawy, a tą wystarczyło zmienić, aby stosownie zawęzić jej prawa. Nie wahano się przy tym wysuwać argumentów bazujących na ideologii minionej epoki - gallikanizm przyznawał dobra francuskiemu Kościołowi pod warunkiem, że utrzymywała się nad nimi władza zwierzchnia monarchy i państwa. Kościół posiadał ziemie na podstawie przywileju, a ten wystarczało cofnąć. W takim zaś razie sekularyzacja była czymś najzupełniej naturalnym. Trudno tu nie wspomnieć, że jednym z mózgów tego procesu okazał się nikt inny jak książę Talleyrand, późniejsza sława dyplomacji, mistrz sofizmatów i obłudy na wodzy politycznych interesów ${ }^{10}$. To właśnie on 10 października 1789 roku zgłosił w Konstytuancie wniosek o przyjęcie reformy i przedłożył stosowny projekt ustawy (o polityczny los projektu na forum izby dbał potem bardziej hrabia Mirabeau, uchwalono go 2 listopada). Zagarnięcie dóbr duchownych i przeciwników politycznych zdecydowało o ekonomicznym przetrwaniu pochłoniętego rewolucyjną gorączką państwa. To zaś stopniowo coraz bardziej zacieśniać chciało swobody swych obywateli, ograniczając przykładowo prawo emigrowania czy działalności gospodarczej. Na propozycje zniesienia niewolnictwa odpowiadano pokrętnie. Przyznawano, że ludzie są równi, jednak podkreślano, że pewne rasy czy nacje do niewoli są nawykłe, zaś ich panów odciąć od zysków w tej mierze byłoby jeszcze większym okrucieństwem (Baszkiewicz, 1993, s. 197-198, 298-301). Z hasłami na wyplenienie tych i innych dowodów na niepełność czy też fałszywość Rewolucji doszli do władzy jakobini i to oni zdecydowali o dalszych dziejach Deklaracji.

(ok. 60\% całości) to dorośli mężczyźni opłacający podatek o najniższej stawce. Wyższej wymagano od wybieranych przez nich elektorów (około 400 tys. obywateli). Elektorzy wybierali deputowanych, którzy musieli być właścicielami nieruchomości oraz opłacać wysoki podatek - 20 do 25 razy wyższy od tego, którego wymagano od obywateli trzeciej kategorii oraz 7 do 10 razy wyższy od podatku elektorów. Poza dziećmi oraz kobietami praw wyborczych nie mieli również ludzie zatrudnieni na służbie. Za powszechnym prawem głosu w Konstytuancie opowiedziało się zaledwie pięciu posłów (Baszkiewicz, 2002, s. 84).

10 Talleyrand miał swój udział w uchwalaniu Deklaracji z 1789 roku - to on zredagował słynny art. 6 o równości wobec prawa, godności i stanowisk oraz prawie stanowionym jako woli powszechnej obywateli. O motywach i kulisach postępowania Talleyranda w kwestii sekularyzacji (skądinąd był jeszcze wówczas biskupem diecezji Autun) barwnie piszą jego biografowie (Tarle, 1967, s. 44-50; Orieux, 1989, s. 136-140). 


\title{
2. DEKLARACJA DRUGA (1793)
}

Spisana została na nowo jako wstęp do konstytucji z 24 czerwca 1793 roku (Duguit, Monnier, 1952, s. 66-69). Całość przygotowano i uchwalono błyskawicznie, bo zaledwie w trzy tygodnie, co miało na celu przeszkodzić propagandowym reakcjom opozycji. Deklaracja roku I okazała się najbardziej radykalną ze wszystkich, choć dużo zawdzięczała wcześniejszemu projektowi deklaracji żyrondystów (Duguit, Monnier, 1952, s. 36-38), który złożyli Konwentowi wraz z projektem całej konstytucji w kwietniu tego samego roku (liczne artykuły zostały wręcz inkorporowane w całości). Deklaracja i konstytucja nie były pełną realizacją programu politycznego jakobinów - jak pisał Konstanty Grzybowski, było to kompromisem, nie z przeciwnikiem, gdyż ten został zlikwidowany, lecz z rzeczywistością:

\begin{abstract}
„Rzeczywistość kazała liczyć się z prowincją, ogromną większością Francuzów niechętną Paryżowi”. Z tego powodu nie wprowadzono odwołań do „świeckiej religii rewolucyjnej”, ani jeszcze mniej liberalnie ujętej własności prywatnej, którą postulował Robespierre. Nie powiódł się również plan wprowadzenia do ustawy zasadniczej radykalnego zcentralizowania administracji państwa (Grzybowski, 1947, s. 28-29).
\end{abstract}

Wyliczając przypadki, poszła jednak o wiele dalej - nade wszystko nadając demokratycznemu ustrojowi państwa tak wyraźne akcenty etyczne - celem społeczeństwa staje się „,szczęście ogółu” (art. 1). Ustawodawca wierzy w swą zdolność do określenia, co będzie dla ludu właściwe, tworząc jednocześnie koncepcję „dobrego obywatela”, który będzie postępował nie tylko w granicach obowiązującego prawa, ale również wedle przykazań moralnych - wolność z artykułu 6 to również trzymanie się zasady „nie czyń drugiemu, czego nie chcesz, by tobie czyniono”. Równolegle nastąpić ma kreacja „nowej moralności demokratycznej” przez władzę silną, zdolną do głębokiego przebudowania podstaw systemu społecznego (Morabito, Bourmaud, 1996, s. 132).

Zmienia się hierarchia praw człowieka i obywatela. W kolejności będą to: równość, wolność, bezpieczeństwo, własność (art. 2). Równości nie interpretuje się jedynie w ujęciu liberalnym, lecz również egalitarnym, „arytmetycznym”: „wszyscy ludzie są równi z samej natury i prawa”. Wśród ideologicznych inspiratorów praw Francuzów na pozycję lidera wysuwa się w tym momencie Rousseau. Suwerenem nie jest już „Naród” (la Nation), jak stanowił art. 3 Deklaracji z 1789 roku, lecz „lud” - le peuple (art. 25 jakobińskiej Deklaracji). Zmiana o tyle istotna, że określenie „Naród” mogło kojarzyć się z uprzednimi ograniczeniami życia poli- 
tycznego, spod znaku pays legal - z systemem cenzusu majątkowego (Grzybowski, 1947, s. 29-30). Nic nie stało na przeszkodzie, by suwerenny, równy lud mógł zmienić konstytucję (art. 28), wręcz podkreślono, że jedno pokolenie nie mogło narzucać swych praw pokoleniom następnym. W istocie tak wszechwładnego ludu nie krępowało go już zgoła nic.

Jak w praktyce ma dochodzić do zapewnienia owej faktycznej równości? Już przy pracach nad poprzednimi projektami deklaracji pojawiały się propozycje praw o charakterze socjalnym, zawarto je również w projekcie żyrondystów. W tym momencie zostają usankcjonowane i stosownie rozszerzone w stosunku do wcześniejszych prób: prawo do pracy, pomocy społecznej, powszechnej oświaty (szczególnie ważny postulat dla Rousseau) ${ }^{11}$. Jednocześnie własność prywatna - choć nadal chroniona (art. 16) i przysługująca każdemu Francuzowi, który może swobodnie jej używać i rozporządzać - nie jest już, jak w pierwszej Deklaracji, opisywana jako „święta” i „nienaruszalna”. I pomimo zawarcia zakazu wywłaszczania powtarzającego co do zasady gwarancje z pierwszej Deklaracji (art. 19), dawało to nadzieję na budowę wyśnionej przez Rousseau i Robespierre’a „republiki drobnych posiadaczy”, interwencję władzy w system własności, likwidację wielkiego bogactwa i wielkiej biedoty. Ziszcza się tu po raz pierwszy w tak dobitnej postaci wizja „,́wiatopoglądu prawniczego”, wedle którego dobre, bo nowe i sprawiedliwe prawo jest w stanie odmienić społeczeństwo i pojedynczego człowieka. Jako z natury dobry, nie będzie on już nabywał wad takich jak chciwość czy agresja wobec bliźniego, gdyż nowe moralne prawo da mu szansę być człowiekiem w pełni. Na usprawiedliwienie tej szlachetnej naiwności jakobinów, która prowadziła prostą drogą do uszczęśliwiania na siłę, można powiedzieć, że byli prekursorami. Nie brakowało jednak przecież krytyków, którzy wołali przeciw tej i innym podobnym utopiom, i to na długo przed próbami jej realizacji w praktyce. Już David Hume w swych Badaniach dotyczq̨cych zasad moralności przestrzegał przed radykalnymi pomysłami egalitarnymi, wróżąc, że wykorzenianie pewnych naturalnie ugruntowanych w ludziach cech doprowadzi do tyranii wszechwiedzącej, wyobcowanej władzy.

11 Bez nowej edukacji i wychowania nie ma szans na prawdziwie wolnych i równych ludzi. Warto tylko pamiętać, że Rousseau pisał nieco inaczej o wychowaniu w swym słynnym Emilu oraz w Uwagach o rzq̨dzie polskim. W pierwszym dziele chodziło o naturalny rozwój jednostki przy udziale troskliwego nauczyciela, osobistego mentora, kiedy w piśmie adresowanym do Polaków skłaniał się do masowej edukacji patriotycznej, obywatelskiej, przy udziale dobroczynnych i zasłużonych, lecz nieprofesjonalnych „starszych”. Można w tym widzieć ewolucję jego poglądów, ale też i przygotowanie recepty na zmianę stosunków w zagrożonym politycznie kraju, do którego adresował swe dzieło. Podobne poglądy przedstawił w niedokończonym Projekcie konstytucji dla Korsyki. 
W tekście jakobińskiej Deklaracji znajdują się jednak artykuły mające w sposób niebudzący najmniejszej wątpliwości chronić społeczeństwo przed najmniejszą choćby groźbą despocji. Każdej osobie, która uzurpować sobie będzie władzę suwerenną, nawet nie grozi, ale wręcz przysługuje kara śmierci wymierzona przez „ludzi wolnych” (art. 27). Natomiast prawo oporu, uchwalone w brzmieniu zaproponowanym przez Robespierre’a, staje się czymś o wiele bardziej zasadniczym podstawowym obowiązkiem obywateli. Kiedy rząd gwałci ich prawa, należy zwołać insurekcję (art. 35). Tak samo obywatel ma prawo odeprzeć każdy samowolny czyn skierowany wobec niego (art. 11), jest chroniony przed nadużyciami władzy. Podobnie jak w poprzedniej Deklaracji, cieszy się zasadą nietykalności osobistej (art. 10), domniemaniem niewinności (art. 13). Podsądny dysponuje gwarancjami procesowymi, ustawy nie działają wstecz, kary muszą być proporcjonalne do popełnionych przestępstw i społecznie użyteczne (art. 14-15), przez co realizować się miała doktryna humanitarna prawa karnego. Zwłaszcza ta część Deklaracji kłóci się z utrwalonym powszechnie obrazem rządów jakobinów. W istocie ów pomysł na państwo i prawo nie miał okazji na wprowadzenie w praktykę. Z uwagi na sytuację wewnętrzną i zewnętrzną kraju, konstytucja roku I została zawieszona, podobnie jak jej Deklaracja. Jedynie wprowadzenie w życie wreszcie spójnej z deklarowaną zasadą suwerenności ludu zasady powszechności wyborów do Konwentu stanowiło niewątpliwy krok na przód, choć władza tego ciała była skutecznie ograniczona w praktyce ${ }^{12}$. Spełniły się proroctwa Rousseau:

Dodajmy, że nie ma rządu tak narażonego na wojny domowe i zaburzenia wewnętrzne, jak właśnie rząd demokratyczny, czyli ludowy, albowiem żaden inny rząd nie dąży tak usilnie i stale do zmiany ustroju i zachowanie żadnego ustroju nie wymaga większej czujności i odwagi niż w przypadku demokracji (Rousseau, 1966, s. 81).

Twarde rządy Komitetów wykorzystujące „,zerwony terror” okazały się jednak na tyle skuteczne, że ocaliły republikę, choć społeczne koszty tego były ogromne. W rezultacie władzę przejęła ekipa o poglądach krańcowo odmiennych, choć w założeniach swych nadal chcąca kontynuować rewolucyjny nurt przemian.

12 Warto jednak zaznaczyć, że zasada powszechności wyborów również znalazła się w projekcie deklaracji żyrondystów. 


\section{DEKLARACJA TRZECIA (1795)}

„Kraj nie był ani jakobińskim, ani rojalistycznym” - zauważał Louis Madelin:

Rewolucję przyjął już w jej podstawowych prawach, tych, które ogłosił rok 1789. $Z$ drugiej strony rewolucja wytworzyła przy tym nowy stan posiadania. Miliony chłopów wykupiło dobra zabrane szlachcie i duchowieństwu i nowi ci właściciele stanowili zwartą masę. Nie chcieli ani nowej rewolucji, ani kontrrewolucji. Byli więc przeciwni planom tak komunistów, jak i skrajnych rojalistów. Wszyscy żądali rządu ładu i wolności, zachowania wielkich zasad i istoty zdobytych praw (Madelin, 1923, s. 16).

Znamienny był już tytuł dokumentu z 1795 roku - Deklaracja praw i obowiązków człowieka i obywatela (Duguit, Monnier, 1952, s. 78-80). Przyjęto nazwę proponowaną już wcześniej, która okazała się odzwierciedleniem konserwatywnych poglądów termidorianów, reprezentujących siły wielkiej burżuazji ${ }^{13}$. Bogaczom zależało na zapewnieniu porządku publicznego, poskromieniu rozjuszonych w ostatnich burzliwych latach mas ludowych. „Chcieliśmy powiedzieć Francuzom, że nie powinni posłużyć się Deklaracją praw, przybywając pod sztandarami rewolty, aby oznajmić ustawodawcom swe buntownicze zamiary” - wyraził się jeden z redaktorów konstytucji, Jean-Denis Lanjuinais (Morabito, Bourmaud, 1996, s. 157). Trudno zatem dziwić się wyeliminowaniu wszelkich zapisów, które zachęcałyby do obywatelskiego nieposłuszeństwa, z prawem do oporu na czele.

Francuzi otrzymali 22 prawa i 9 obowiązków usadowionych w dwóch osobnych podrozdziałach. Zapisano je lakonicznym, suchym, urzędniczym językiem, dalekim od wzniosłości poprzednich dwóch tekstów, choć te były bazą dla trzeciej deklaracji. Treść jej z oczywistych względów bardziej nawiązywała do pierwszej, choć w sposób stosownie zubożony. Wszystko to, a także sam plon późniejszych rządów Dyrektoriatu spowodowało, że owo bardziej konserwatywne dzieło Rewolucji nie budziło wśród historyków państwa i prawa większych uczuć, było

13 Podczas prac nad pierwszą Deklaracją bardziej radykalni deputowani czujnie stopowali wszelkie próby zapisania tam również obowiązków obywatelskich, uznając, że dziejowa chwila, w jakiej znalazła się Francja po zrzuceniu kajdan absolutyzmu, nie pozwalała na podobne zabiegi, na nakładanie nowych przykazów. Byli skądinąd i reprezentanci uznający przyjęty tekst za zbyt ostrożny i żądający jeszcze większej dozy swobód. Jeden z najpopularniejszych polityków, „uosobienie Rewolucji”, hrabia Honoré de Mirabeau domagał się chociażby obywatelskiego prawa noszenia broni i używania jej dla obrony (Baszkiewicz, 1993, s. 69). 
traktowane marginalnie, wręcz lekceważone. Podobnie jak w dokumencie jakobińskim zabrakło artykułu wzorowanego na amerykańskim art. 1 z 1789 roku: „Wszyscy rodzą się i pozostają wolni oraz równi wobec praw...”14. W zamian, podobnie jak w 1793 roku, wyliczono hierarchię praw człowieka, tyle że oczywiście zmodyfikowaną: wolność, równość, bezpieczeństwo, własność (art. 1 praw). Na pierwsze miejsce powróciła zatem wolność. Natomiast równość nie ma już, jak u jakobinów, wymiaru faktycznego, społecznego, a jest znów jedynie równością wobec prawa - zarówno wobec regulacji przyzwalających, jak i karzących. Dla pewności dodano jeszcze zdanie, że w tak pomyślanym systemie nie ma miejsca na różnice wynikające z urodzenia, na dziedziczenie osobistych uprawnień (art. 3 praw). Nie ma już mowy o prawach socjalnych z 1793 roku, prawie do pracy, do pomocy społecznej czy oświaty. Zrezygnowano nawet z zapisu o swobodzie wyznań religijnych i wolności prasy. Wprowadzono natomiast ważną zdobycz „górali”: zakaz niewolnictwa, który Konwent uchwalił 4 lutego 1794 roku. Artykuł 15 Deklaracji praw z 1795 roku stanowił, że każdy człowiek może poświęcać swój czas i usługi, ale nie może sprzedać swej osoby ani nie może zostać sprzedanym; jego osoba nie może być przedmiotem zbywalnej własności. Te szczytne osiągi prawne przekreślone zostały jednak rychło przez przywrócenie niewolnictwa w koloniach za czasów napoleońskich (1802).

Również jakobińskich wpływów upatruje się w nadaniu moralnego wymiaru treści Deklaracji z 1795 roku. Potrzebę zawarcia w Deklaracji obowiązków obywateli wyjaśnia art. 1 podrozdziału je wymieniającego: utrzymanie społeczeństwa wymaga, aby ci, którzy się na nie składają, powinni również znać i wypełniać swoje obowiązki. Obowiązki wywodzą się z naturalnych przykazań, aby nie czynić innym tego, czego samemu nie chciałoby się odczuć oraz by czynić dobrze, jeśli chce się dobro otrzymywać (art. 2 obowiązków). Obywatel winien służyć społeczeństwu, bronić go, żyć zgodnie z prawem i szanować instytucje publiczne (art. 3 obowiązków). Znów mowa o „dobrym obywatelu”, ale już nie w optyce jakobińskiego pochylenia się nad prostym ludem, lecz w granicach etyki mieszczańskiej - „Nie jest dobrym obywatelem ten, kto nie jest dobrym synem, dobrym ojcem, dobrym przyjacielem, dobrym małżonkiem” (art. 4 obowiązków). Deklaracja zapewnia przy tym, że nie jest uczciwym człowiekiem ten, kto szczerze i skrupulatnie nie przestrzega prawa (art. 5 obowiązków), a jeśli prawo odważy się złamać, oznaczać to będzie wypowiedzenie wojny społeczeństwu (art. 6 obowiązków). Ostatnie

14 J.-D. Lanjuinais: „Jeśli mówicie, że wszyscy ludzie pozostają równi w swych prawach, prowokujecie do rewolty przeciw Konstytucji tych, którym odmówiliście lub którym zawiesiliście wykonywanie praw obywatelskich dla bezpieczeństwa wszystkich”. (Morabito, Bourmaud, 1996, s. 156). 
trzy obowiązki przekraczają w istocie granice moralistycznego banału, grzmiąc o utracie społecznego szacunku wobec osób łamiących prawo i działających przez to wbrew interesom ogółu, przypominając o potrzebie utrzymywania w należytym stanie własności, uprawie ziemi, prowadzeniu wszelkich potrzebnych produkcji, dbaniu o środki pracy, jako że wszystkie te elementy stanowią o podstawach porządku publicznego. Ostatni artykuł powtarza, że każdy obywatel powinien osobiście stawić się na wezwanie do obrony swego kraju, w którym cieszy się wolnością, równością, własnością.

Sprzyjający burżuazji termidorianie łączyli majętność z odpowiedzialnością za państwo. W tak pomyślanym świecie nie było już miejsca na faktyczną równość głosowania, do konstytucji roku III powróciły cenzusy. Jednocześnie do Deklaracji wróciła wyrzucona przez jakobinów zasada trójpodziału władzy. Przepis to stanowiący daleki był jednak od finezji i dobitności pierwowzoru La Fayette’a z 1789 roku, jednak dawał w zamian zapowiedź większej kontroli osób sprawujących administrację: „Nie może egzystować gwarancja społeczna tam, gdzie nie został zapewniony podział władz, gdzie nie wytyczono między nimi granic i gdzie nie zapewniono odpowiedzialności urzędników służby cywilnej” (art. 22 praw). Strach przed dyktaturą spowodował skomplikowany i niepraktyczny system organów władzy ustawodawczej i wykonawczej w konstytucji. Niepowodzenie tych rozwiązań okazało się jednak w praktyce kompletne. Nieefektywny i skorumpowany system (którego negatywnym symbolem stał się najbardziej wpływowy z pięciu dyrektorów - Paul Barras), szybko został przez lud znienawidzony na równi z praktyką rządów jakobińskiego „czerwonego terroru”.

\section{DZIEDZICTWO DEKLARACJI}

W kolejnej ustawie zasadniczej - ustawie roku VIII, czyli tzw. konstytucji konsularnej z 13 grudnia 1799 roku - zabraknie deklaracji praw obywatelskich. Czy Francuzi nie wierzą już w karty uświęconych gwarancji, którym wcześniej oddawali niemalże religijną cześć? ${ }^{15}$. Przy aplauzie ludu Napoleon buduje zręby

15 Deklaracje od początku sprawdzały się jako atrakcyjne symbole rewolucyjne, reprodukok wane na niezliczonej liczbie grafik, rysunków i obrazów mających zwykle postać symbolicznych, alegorycznych przedstawień. Niejednokrotnie przypominały na nich biblijne tablice Mojżesza. W takiej formie pojawiały się często na masowych uroczystościach, paradach, pochodach. Tak pismo „Révolutions de Paris” relacjonowało w 1792 roku obchody święta ku czci buntu Szwajcarów z Châteauvieux, rebeliantów z sierpnia 1790 skazanych na galery: „Dla przepychu nie było więc miejsca; ale niesione w odstępach przedmioty pamięci przemawiały do myśli i do serca. Pochód 
zupełnie nowego systemu, gdzie przy pewnej dozie resentymentów dla ancien régime silną ręką ma nieść obywatelom ład, przy jednoczesnym wyrywkowym użyciu rewolucyjnych haseł. Jednak koleje dziejów pokazały, że moc pierwszej Deklaracji będzie już na zawsze dla Francuzów punktem odniesienia, fundamentem obywatelskiego etosu ${ }^{16}$. Wyraźne efekty tego były widoczne przy okazji wszystkich kolejnych niepokojów rewolucyjnych, do spuścizny tej zwracały się zarówno nurty opozycji radykalno-demokratycznej, jak i ekipy rządzące, zwłaszcza w czasach II i III republiki. Z wagi utrwalonej w ludzie świadomości o jego prawach zdawali sobie sprawę najbardziej konserwatywni z rządzących. Nawet w reakcyjnej Karcie konstytucyjnej z 4 czerwca 1814 roku znalazła się przecież garstka praw obywatelskich, dowodząc, że przywrócenie w całości systemu sprzed 1789 roku było niemożliwością. Wszelako nigdy później nie uchwalono już we Francji kolejnej Deklaracji praw. Najbardziej zaawansowane prace nad takim dokumentem miały miejsce w 1848 roku, jednak w ostateczności konstytucja II republiki z 21 listopada tegoż roku zawarła jedynie skromną preambułę z ośmioma artykułami opisującymi prawa i obowiązki obywateli. Mimo tego część podręczników historycznoprawnych mylnie traktuje o poprzedzeniu tej ustawy zasadniczej deklaracją praw. We wprowadzonej trzy lata później konstytucji Ludwika Napoleona z 14 stycznia 1852 roku znalazł się art. 1 stanowiący, że zasady wypracowane w 1789 roku stanowić mają fundament prawa publicznego.

Zapis utrzymał się po przekształceniu tej ustawy w konstytucję II cesarstwa, do czego doszło już w grudniu 1852 roku. Z przyczyn politycznych (trudności

otwierała Deklaracja Praw Człowieka, wyryta na dwóch kamiennych tablicach - tak jak przedstawia się nam dekalog Hebrajczyków, który nie może się z nią równać. Czterech obywateli niosło z dumą na ramionach to czcigodne brzemię; a kiedy się zatrzymywali, by odpocząć lub poczekać na resztę orszaku, zaraz wokół nich gromadziła się liczna grupa i każdy odczytywał głośno, z poczuciem dumy i sprawiedliwości, pierwsze zdanie Deklaracji: ludzie rodzą się i pozostają wolni i równi” (Ozouf, 2008, s. 88). Teksty Deklaracji i konstytucji rewolucyjnych bywały uczone w całości na pamięć, deklamowane publicznie. Często skłaniano do tego dzieci. Stąd finałowa, przejmująca scena w filmie Andrzeja Wajdy Danton, z małoletnim bratem wielbicielki Robespierre’a, Eleonory Duplay (jej rodzice wynajmowali politykowi mieszkanie), recytującym choremu i przerażonemu krwawą rozprawą z dantonistami Maksymilianowi całość Deklaracji, ma nie tylko wymiar symbolu. Z drugiej strony twórcy obrazu zdecydowali, że recytowany będzie bardziej rozpoznawalny i dobitniej brzmiący tekst z 1789, a nie bardziej tu adekwatny z 1793 roku. Historycznym konsultantem Dantona był sam J. Baszkiewicz, który potem wraca pamięcią do tej sceny, choć już nie wchodzi w szczegóły doboru ostatecznego tekstu recytacji. Podkreśla przy tym, że w planach jakobińskiej reformy edukacji było powszechne nauczanie zasad konstytucji i głównych idei Deklaracji praw (Baszkiewicz, 1993, s. 91).

16 Deklaracja jakobińska, choć mniej nośna, również będzie inspirować - zdarzenia Wiosny Ludów, program Komuny Paryskiej czy ustawodawstwo socjalne, które zaczęto wprowadzać w życie w Europie w końcu XIX wieku (Sójka-Zielińska, 2010, s. 153). 
w zapewnieniu większości głosów podczas uchwalania) nie zawarto ani praw obywatelskich, ani jakichkolwiek odwołań do przeszłości w konstytucji III republiki z 1875 roku, jednak budowano demokratyczny system parlamentarny, odwołując się po części do ideologicznego dorobku Rewolucji. Podkreślać się zresztą będzie, że pierwsza Deklaracja, nigdy formalnie nieodwołana, obowiązywała nadal. A w rezultacie, że obowiązuje do dziś dnia. Rada Konstytucyjna Francji bada obecnie zgodność ustaw nie tylko z konstytucją V republiki z 1958 roku, lecz również z tekstem z 26 sierpnia 1789 roku.

\section{Bibliografia:}

Arendt, H. (1991). O rewolucji, Kraków: Wydawnictwo X i Dom wydawniczy TOTUS.

Baszkiewicz, J. (2002). Liberté chérie. W: J. Baszkiewicz (red.), Francja nowożytna.

Szkice z historii wieków XVII-XX (s. 60-100). Poznań: Wydawnictwo Poznańskie.

Baszkiewicz, J. (1993). Nowy człowiek, nowy naród, nowy świat. Mitologia i rzeczywistość rewolucji francuskiej. Warszawa: Państwowy Instytut Wydawniczy.

Burke, E. (2012). O duchu i naturze rewolucji francuskiej w odniesieniu do innych krajów.

E. Burke (red.), O duchu i naturze rewolucji. Kraków: Księgarnia Akademicka Sp. Z 0.0 .

Duguit L., Monnier, H (1952). Les constitutiones et les principales lois politiques de la France depuis 1789. Paris: Librairie générale de droit et de jurisprudence R. Pichon et

R. Durand-Auzias. Teksty źródłowe deklaracji.

Grzybowski, K. (1947). Demokracja francuska. Warszawa: Czytelnik.

Jellinek, G. (1905). Deklaracja praw człowieka i obywatela. Warszawa: Skład główny w Księgarni Powszechnej.

Madelin, L. (1923). Francja Dyrektorjatu. Kraków: Stow. Przyjaciół Francji w Krakowie. Morabito, M., Bourmaud, D. (1996). Historia konstytucyjna i polityczna Francji

(1789-1958). Białystok: „Temida 2”: przy współpr. Wydziału Prawa Uniwersytetu Warszawskiego.

Orieux, J. (1989). Talleyrand. Warszawa: Wydaw. „Współpraca”.

Posner, S. (1907). Deklaracja praw człowieka i obywatela. Warszawa: skład główny w Księgarni Naukowej.

Rousseau, J.J. (1966). Umowa społeczna. W: J.J. Rousseau (red.), Umowa społeczna. Uwagi o rządzie polskim. List o widowiskach (s. 3-177). Warszawa: PWN.

Sójka-Zielińska, K. (2010). Drogi i bezdroża prawa. Szkice z dziejów kultury prawnej

Europy. Wrocław: Zakład Narodowy im. Ossolińskich.

Tarle, E. (1967). Talleyrand. Warszawa: Książka i Wiedza.

Tocqueville, A. de (2005). Dawny ustrój i rewolucja. Warszawa: Fundacja „Aletheia”. 
